\title{
Article \\ Civic Crowdfunding in Local Governments: Variables for Success in the Netherlands?
}

\author{
Kees Van Montfort ${ }^{1}{ }^{*}$, Vinitha Siebers ${ }^{2}$ and Frank Jan De Graaf ${ }^{1}$ \\ 1 Centre for Applied Research on Economics and Management, Amsterdam University of Applied Sciences, \\ Wibautstraat 3b, 1091 GH Amsterdam, The Netherlands; F.J.de.Graaf@hva.nl \\ 2 School of Business and Economics, VU University Amsterdam, de Boelelaan, \\ 1081 HV Amsterdam, The Netherlands; v.m.siebers24@gmail.com \\ * Correspondence: c.a.g.m.van.montfort@hva.nl
}

Citation: Van Montfort, Kees, Vinitha Siebers, and Frank Jan De Graaf. 2021 Civic Crowdfunding in Local Governments: Variables for Success in the Netherlands? Journal of Risk and Financial Management 14: 8. https:// doi.org/10.3390/jrfm14010008

Received: 29 November 2020 Accepted: 22 December 2020 Published: 25 December 2020

Publisher's Note: MDPI stays neutral with regard to jurisdictional clai$\mathrm{ms}$ in published maps and institutional affiliations.

Copyright: (C) 2020 by the authors. Licensee MDPI, Basel, Switzerland. This article is an open access article distributed under the terms and conditions of the Creative Commons Attribution (CC BY) license (https:// creativecommons.org/licenses/by/ $4.0 /)$.

\begin{abstract}
By using information technology, local governments can develop alternative forms of citizen engagement. Civic crowdfunding campaigns supported by online platforms enable citizens to participate financially in social projects and can be matched with government funding. As such, an alternative for subsidies seems to be developing. In this paper, we assess empirically the success of civic crowdfunding campaigns in the Netherlands by using data collected during 2018 from 269 civic crowdfunding projects and local demographic data from the neighborhoods of these projects. The factors- the use of match-funding, the target amount of money, and the theme of the project, as well as the age structure, the province, and the degree of urbanization of the neighborhood of the civic crowdfunding project-turn out to be empirically related to the success of a civic crowdfunding campaign.
\end{abstract}

Keywords: civic crowdfunding projects; citizen engagement; online platforms; success factors of funding campaigns

\section{Introduction}

To manage pressing societal challenges, local governments increasingly tap into the knowledge of citizens. Citizens do not have a voice that can be heard only during elections, but they also have knowledge and capacities that can be used to generate input more often (Roberts 2004; Siebers and Torfing 2018; Mueller et al. 2018). As a result, local governments offer various platforms to engage citizens, for example meetings, dialogue sessions, or citizen panels (Rowe and Frewer 2000).

More specifically it is visible that by the increase in technology, the platforms through which local governments interact with their citizens have changed (Quaintance 2017; Cho et al. 2020; Johnson et al. 2020). Via internet, email or WhatsApp citizens can more easily than before address concerns about municipal matters, or initiatives that they aim to start (Johnson et al. 2020). As a result, relatively simple tasks such as applying for a new passport or even complex interactions such as filing tax returns have become easier. Office opening hours are no longer a decisive factor for when or how citizens interact with the municipality, but citizens themselves determine their moment of interaction. At the same time, the increased use of technology allows for (government) information to be more accessible. This leads to experiments of municipalities with more IT-enabled forms of citizen engagement (Gandhinagar 2015; Hsu et al. 2020). An example of such form is civic crowdfunding.

Civic crowdfunding is a recent technological development. It can be defined as "a sub-type of crowdfunding through which citizens fund projects that provide community service" (Davies 2014, 2015; Stiver et al. 2014, p. 1; Hummel 2016). Often, governments take a role in these crowdfunding projects. They can have a role in a campaign themselves, for example by facilitating the platform, developing communication strategies 
for projects, or acting as co-financier. Although the role of the local government is not necessary, various authors assume a role for local authorities within these initiatives (e.g., Charbit and Desmoulins 2017). Even if municipalities do not have a role in the organization of a campaign, they often have to be involved because of the investments that are made often relate to the public space (e.g., parks and playgrounds).

Civic crowdfunding is seen as a platform that can change the interaction between governments and citizens as it offers communities an alternative means of financing social projects that are normally funded by the government. Advocates suggest that civic crowdfunding strengthens the empowerment of citizens in neighborhoods by enabling them to initiate worthwhile projects within that neighborhood (Brent and Lorah 2019). The growth of civic crowdfunding, therefore, provides opportunities for local governments to facilitate, stimulate, and finance initiatives from citizens. Consequently, it is seen as a new form of citizen engagement in which citizens participate in planning and designing projects (Mueller et al. 2018). Slightly more knowledge of the process of civic crowdfunding campaigns is now available (Brent and Lorah 2019; Cho et al. 2020; Kusumarani and Zo 2019). Despite this, there is still little empirical evidence about factors that contribute to the establishment of civic crowdfunding campaigns (Stiver et al. 2014; Morell et al. 2020) particularly when it comes to acquiring money for such campaigns. It is suggested that civic crowdfunding depends to a great extent on money and attracting funders.

Based on such factors, this paper explores campaign characteristics and local demographic characteristics that support the financing of civic crowdfunding campaigns by examining 269 projects in Dutch municipalities. Therefore, we do not focus on the process and execution of civic crowdfunding projects but aim to shed light on the factors that influence whether enough money was brought in to execute the project properly. The use of match-funding, the target amount of money, and the theme of the project to get attention are among other project issues. In addition, local demographic characteristics of the neighborhood of the projects are included in our analyses. Our empirical results enable us to further specify the role of local governments in this new instrument. By doing this, among other things, we further extend the work of Praharaj et al. (2017), Brent and Lorah (2019), and Cho et al. (2020), which focus mainly on demographic characteristics of the project neighborhoods. We also elaborate on the results of Charbit and Desmoulins (2017), Doan and Toledano (2017), Colasanti et al. (2018), and Kusumarani and Zo (2019), who studied the influence of some campaign characteristics on the success of the funding. Moreover, the empirical analyses are based on data in the European Union, a region where governments tend to be more active in community development then in the US.

This article begins by describing the growing interest in civic crowdfunding and its advantages. This is followed by discussing previous research on civic crowdfunding. After that, an empirical analysis of civic crowdfunding campaigns is made by examining characteristics that contribute to the successful funding of such campaigns. The paper concludes with discussing the main findings and implications for local governments.

\section{The Attention for Civic Crowdfunding}

Civic crowdfunding is a recent development in which individuals raise money using technology (Bastian 2015; Kusumarani and Zo 2019). A crowdfunding platform offers technical facilities for people who want to initiate a certain project (for example, a playground in their neighborhood). In doing so, civic crowdfunding ${ }^{1}$ refers to financing projects that are dedicated to a 'civic' cause that are initiatives originating in the community and supported by individuals or organizations in society (Wenzlaff 2020a, p. 441). The term 'civic' in this case refers to actions within municipalities as well as actions by citizens who pursue a common goal (Wenzlaff 2020b). Civic crowdfunding facilitates making the project visible, transparent, and easy for users to launch and promote a project. Often, the appearance on

1 In current paper the term civic crowdfunding and crowdfunding are used interchangeably. Both terms indicate raising money for a 'civic' cause and is about achieving a common goal. 
a platform is combined with an online campaign, using among other things social media, and offline elements such as flyers, events, and newsletters. It is considered important that a target amount of money needs to be raised and there is an end date; however, there is no insight as to whether this has an impact on the success of a campaign.

Since the start of civic crowdfunding in the United States about 15 years ago, there has been a huge increase in these platforms (Massolution 2015). Next to civic crowdfunding, in which individuals donate money to social projects, other forms of crowdfunding exist. Three forms are distinguished. First is loan-based crowdfunding. This is the mostly popular form and measures crowdfunding in invested capital. In this form the individual investors lend money to an organization via a digital platform in return for interest. A second form is equity-based crowdfunding. This form is similar to loan-based crowdfunding; however, investors receive equity in return. The third form is reward-based crowdfunding. In this form, individuals invest in a certain service or product and-when the product is available - they receive this product. For example, individuals invest in an idea for a movie and when enough money is raised all the investors can go to the cinema to see the result. In practice, combinations of these forms of crowdfunding also exist (Massolution 2015; Miglo 2020). Thus, crowdfunding provides the possibility to implement new ideas or projects and offers a process by which money can be raised online from an individual or a group of individuals in various ways (Ahlers et al. 2015; Miglo 2020). Crowdfunding is therefore used in addition to traditional resources such as investments, venture capital and banking (Miglo 2020; Ullah and Zhou 2020, p. 1).

In the Netherlands too, the interest in crowdfunding has grown. In 2019 alone 424 million Euros were raised via crowdfunding in general, with on average about 32 thousand Euros per project (Crowdfundingcijfers[crowdfunding statistics] 2020). In 2017, 170 million Euros was raised. This amount was triple that raised in 2014 (Douw and Koren 2017). For civic crowdfunding, a similar increase is visible. Civic crowdfunding raised 16.2 million Euros with 8205 projects in 2019. The average amount for civic crowdfunding projects is 2000 Euros, which indicates that there is a serious divide between crowdfunding with a commercial purpose and crowdfunding in which the social objectives are the focus.

Unlike crowdfunding in which the objective is to collect money, by using online social networks focused on commercial objectives (Mollick 2014; Ahlers et al. 2015), the result of civic crowdfunding is the public good, public interest (Davies 2014, 2015; Cheung and Rogers 2020), such as a park or an educational program for the community. Civic crowdfunding comes with several advantages. It fosters the engagement of citizens in a variety of ways. Citizens can participate on a small scale (Kusumarani and Zo 2019) by donating a small amount of money. Furthermore, civic crowdfunding increases the possibility of involvement by offering help to a certain project and rewards the collective by setting up project that foster the community (Gaventa 2002; Fischer 2000; Irvin and Stansbury 2004; Nabatchi and Leighninger 2015). Additionally, civic crowdfunding allows citizens to have a more active role in public decision-making and leads to developing initiatives in their own community. Moreover, it reduces challenges related to the process of citizen engagement. For example, it helps in the selection of certain projects as citizens can decide themselves which projects deserve priority (Charbit and Desmoulins 2017).

\section{Research into Civic Crowdfunding}

In recent years, a few studies have examined civic crowdfunding empirically. These studies focus on different areas such as the motivation to participate in civic crowdfunding. Kusumarani and Zo (2019) reveal that both intrinsic and eccentric motivation contribute to participating in civic crowdfunding, such as rewards, recognition, fun, curiosity, or altruism. Furthermore, it is also known that the factors of the Civic Voluntarism Model (CVM) are motivators for participating in crowdfunding projects and therefore also in civic crowdfunding projects. For example, it is suggested that psychological engagement, such as political interest, and the recruitment network contribute to participation (Baber 2020; Behl and Dutta 2020). Other studies focus on using the advantages of civic crowdfunding. 
Cho et al. (2020) show that the use of online participatory platforms such as crowdfunding is associated with offline participation, goals for citizen engagement, and city size.

Factors that contribute to the execution of civic crowdfunding have also been studied, more specifically these studies reveal factors that contribute to the success of civic crowdfunding. Praharaj et al. (2017) for example, reveal that greater access to digital infrastructure such as internet and mobile phone, as well as availability of skilled workforce, does not necessarily lead to successful civic crowdfunding. Charbit and Desmoulins (2017) suggest that the local nature of a social project is an important factor for civic crowdfunding and can contribute to its success. They also reveal that communication is a key factor for successful civic crowding. Following that, Stiver et al. (2014) illustrate that the factor proximity is important for a civic crowdfunding project. They suggest that to benefit from such projects it is necessary to live in the immediate vicinity of the project. According to them this physical proximity brings several benefits. For example, it helps to facilitate financial support for the project and aids the deployment of volunteers or of making things available. This finding is in line with the study of Brent and Lorah (2019), which shows that distance of the donor to projects plays a role in successful funding civic crowdfunding campaigns, whereby they suggest taking into consideration who is donating. Some projects attract local donations, and some attract donors from all over the country, indicating that geography is an important element.

In conclusion, an amount of diverse information about civic crowdfunding is already available (e.g., motivation, advantages, and success factors). Despite this, a civic crowdfunding project depends mostly on donations and rewards from individuals due to its non-profit driven nature. Finding investors is often seen as the biggest challenge and is perceived as an important contributor to the success of it (Stiver et al. 2014; Hummel 2016; Charbit and Desmoulins 2017). Nonetheless, there is still little knowledge about how civic crowdfunding is applied in practice and what makes it successful (Quaintance 2017; Gandhinagar 2015; Bastian 2015). As municipalities increasingly use IT-enabled forms, such as civic crowdfunding, insights in the factors that contribute to the success of such forms are helpful.

\section{Current Study}

The current paper focuses on examining which factors contribute positively to the success of civic crowdfunding campaigns in the Netherlands (Porter and Veenswijk 2018). We thereby add to the growing body of research on civic crowdfunding by analyzing specific merits of such campaigns that seem to be critical to funding and that have not been studied extensively before (Stiver et al. 2014; Gandhinagar 2015; Bastian 2015; Charbit and Desmoulins 2017; Quaintance 2017; Kusumarani and Zo 2019). Furthermore, we add to the research of Charbit and Desmoulins (2017), Brent and Lorah (2019), and Kusumarani and Zo (2019) by assessing if the success of a civic crowdfunding campaign depends on local demographic characteristics of the project neighborhood. Traditionally, Dutch authorities are very active in developing projects within and for the community. We try to understand the implications of various forms of government engagement in civic crowdfunding. For example, is co- or match-funding relevant, and do the amount of money and the theme of the project have an impact on the success of a campaign? Also, we take demographic characteristics into our analyses such as age structure, the province, and the degree of urbanization of the neighborhood of the civic crowdfunding project.

This study is part of a two-year study in which the organization of various online platforms for participation in the Netherlands is examined. As part of this study, an expert panel concluded that the above-mentioned characteristics are important for predicting the success of civic crowdfunding campaigns. Examining the contribution of such characteristics helps to expand and execute civic crowdfunding. In the next sections we investigate empirically which campaign and local demographic characteristics of the neighborhoods facilitate civic crowdfunding. 


\section{Materials and Methods}

\subsection{Sample}

To analyze the characteristics that facilitate civic crowdfunding campaigns in the Netherlands we use two data sources. The first focuses on campaign characteristics, which are obtained from Dutch civic crowdfunding projects that all were initiated by online civic crowdfunding platforms in 2018. The data contains information on specific characteristics of civic crowdfunding campaigns. The variables of interest are the target earnings in Euros, the realized earnings in Euros, and the attainment of match-funding, meaning if the amount of money that is funded by private persons or organizations will also be funded by the municipality (yes or no), and the use of an all-or-nothing principle (yes or no). This principle indicates that if the collected amount of money does not exceed the $80 \%$ threshold of the target amount of money the civic crowdfunding project will be cancelled $^{2}$. Other variables of interest are the project theme (e.g., Animals, Public Meetings, Green \& Nature, Sport \& Games, Care \& Welfare, Social Entrepreneurship, Education \& Youth, Art \& Culture, Sustainability, and Food), the name of the online civic crowdfunding platform which supports the civic crowdfunding project (i.e., ten different online civic crowdfunding platforms), and the name of the neighborhood in which the crowdfunding campaign took place. In total data of 269 civic crowdfunding projects are in the project data source (see Table 1).

Table 1. Characteristics of 269 civic crowdfunding campaigns in data source.

\begin{tabular}{ccc}
\hline Characteristics & & \\
\hline Target funding (euros) & $\begin{array}{c}\text { Total } \\
1651 \text { million }\end{array}$ & $\begin{array}{c}\text { Average per project } \\
6136\end{array}$ \\
\hline Realized funding (euros) & $\begin{array}{c}\text { Total } \\
1293 \text { million }\end{array}$ & $\begin{array}{c}\text { Average per project } \\
4805\end{array}$ \\
\hline $\begin{array}{c}\text { Ratio of realized funding and target } \\
\text { funding (multiplied by 100) }\end{array}$ & Average Percentage \\
\hline $\begin{array}{c}\text { Match-funding } \\
\text { (percentages) }\end{array}$ & Yes & No \\
\hline $\begin{array}{c}\text { All-or-nothing principle } \\
\text { Number of campaigns } \\
\text { (percentages) }\end{array}$ & Yes & 148 (55.0\%) \\
\hline $\begin{array}{l}\text { Note: The projects in which the all-or-nothing principle was applied and less than } 80 \% \text { of the target amount of } \\
\text { money was raised are included in this table. }\end{array}$ & 249 (92.6\%) \\
\hline
\end{tabular}

The second data source has information on local demographic characteristics of Dutch neighborhoods. The data derives from the Dutch Central Office of Official Statistics (CBS). The primary variables for this paper are population density (i.e., the number of inhabitants per squared kilometer expressed in terms of thousands), crime rate defined by the number of criminal events per thousand inhabitants, percentage of rented homes, percentages of homeowners, percentage one-person households, age distribution ${ }^{3}$, income distribution $^{4}$, province ${ }^{5}$ and the name of the neighborhood. There is roughly data of 16,000

2 The $80 \%$ threshold is an agreed percentage between Dutch municipalities and the national government in the Netherlands.

3 To compare the age distribution dummies were developed. Dummy 1 involves citizens between 0 and 14 years old. Dummy 2 involves citizens between 15 and 24 years old. Dummy 3 involves citizens between 25 and 44 years old. Dummy 4 involves citizens between 45 and 64 years and dummy 5 involves citizens above 65 years old.

4 Meaning percentages of households within the group of 20\% highest incomes, and percentage households within the group of $40 \%$ lowest incomes.

5 Dummies are developed for province to explore the impact of this demographic characteristic on civic crowdfunding campaigns. In total 8 dummies were created. These were: a dummy indicating North, a dummy indicating Gelderland, a dummy indicating Utrecht, a dummy indicating Flevoland, a dummy indicating North Holland, a dummy indicating South Holland, a dummy indicting North Brabant, and dummy indicating Limburg. 
neighborhoods and about 3000 areas in the Netherlands. To gain insight into characteristics that contribute to civic crowdfunding campaigns, both data sources mentioned are merged via the matching variable neighborhood.

\subsection{Procedure}

To understand which campaign and local demographic characteristics relate to the success of civic crowdfunding campaigns mixed regression models were developed (West et al. 2007). The random effects of the mixed regression models represent the different supporting platforms. Mixed regression models are used because each of the ten different civic crowdfunding platforms has its own way of collecting money to fund its projects. As the funding campaigns can vary over the different platforms, a mixed regression model, instead of a classic linear regression model, is most suitable as it captures the dependency between civic crowdfunding projects supported by the same platform.

In the Netherlands, the all-or-nothing principle is applied, and a project is cancelled if less than $80 \%$ of the target money is achieved, as we mentioned earlier. Therefore, the success of a civic crowdfunding campaign could be indicated by the ratio of the realized earnings and the target earnings of the campaign. This variable is used as the dependent variable in the mixed regression models. It should be noted that this variable represents only a measurement of success and is seen as important for passing of the project (cf. Charbit and Desmoulins 2017).

The first mixed regression model examines the influence of specified campaign characteristics on the success of civic crowdfunding campaigns. The campaign characteristics, as mentioned in the previous paragraphs, are defined as the independent variables of this mixed regression model, i.e., match-funding (yes or no), principle all-or-nothing (yes or no), the target amount of money and the project theme.

The second mixed regression model examines the influence of local demographic characteristics of the neighborhood on the success of civic crowdfunding campaigns. The previously identified local demographic characteristics of the neighborhood in this case are defined as the independent variables in this second mixed regression model.

The correlation analyses between the independent variables show that the population intensity is closely correlated with the crime rate (correlation coefficient 0.58 ), the percentage of rented homes (correlation coefficient 0.67 ), and the percentage of homes owned by the households (correlation coefficient-0.67). Moreover, the percentage low household incomes and the percentage high household incomes are strongly negatively correlated (correlation coefficient-0.83). To avoid collinearity, we removed the independent variables crime rate, percentage of rented homes, percentage of homes owned by the households, and percentage low household incomes in the second mixed regression model.

Furthermore, for the variables age and province dummy variables were developed, indicating a specific age group or province. To get a proper specified mixed regression model, we arbitrarily choose the age group "between 15-24 years of age" and the province "North" as the reference groups. As a consequence, the corresponding dummy variables were dropped from both mixed regression models.

Both mixed linear regression models meet the requirements for satisfactory multiple (mixed) regression analyses (Hair et al. 2010, p. 176). The results of the mixed regression models are used to give insight into the factors that facilitate civic crowdfunding campaigns.

\section{Results}

We begin by presenting basic information on our dependent variable, i.e., the success ratio which is defined as the ratio of the realized earnings and the target earnings. Figure 1 shows the success ratios of the 269 projects in our data sources. A project is successful when the success ratio is above $80 \%$. The figure shows that about $22 \%$ of the civic crowdfunding projects did not met this requirement and failed. About $78 \%$ of the campaigns did meet the $80 \%$ requirement and can be defined as successful. 


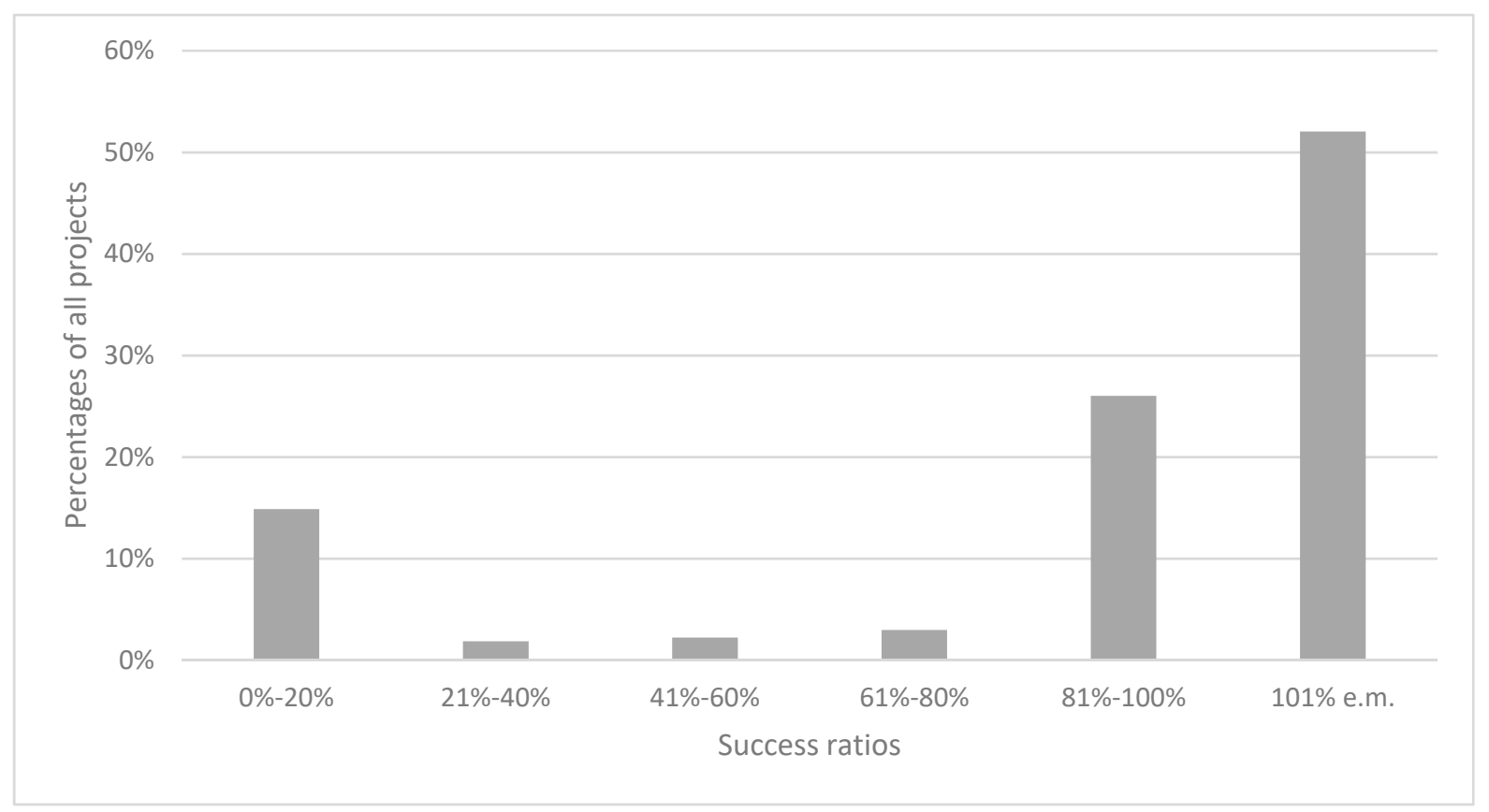

Figure 1. Distribution of success ratios of 269 civic crowdfunding projects, i.e., ratios of realized earnings and target earnings (vertical axis: percentage of all projects; horizontal axis: success ratios of civic crowdfunding projects).

In addition, we examined the average success ratios per project theme. Figure 2 shows that the themes Animals (success ratio 114.6\%; 17 projects) and Public Meetings (success ratio 109.1\%; 38 projects) are the most popular and receive the most funding. These themes are therefore most successful. The theme Food is less successful (success ratio $75.0 \%$; 4 projects). Due to the small number of Food projects, it cannot be concluded that Food funding campaigns are less popular than the other projects and are therefore less successful.

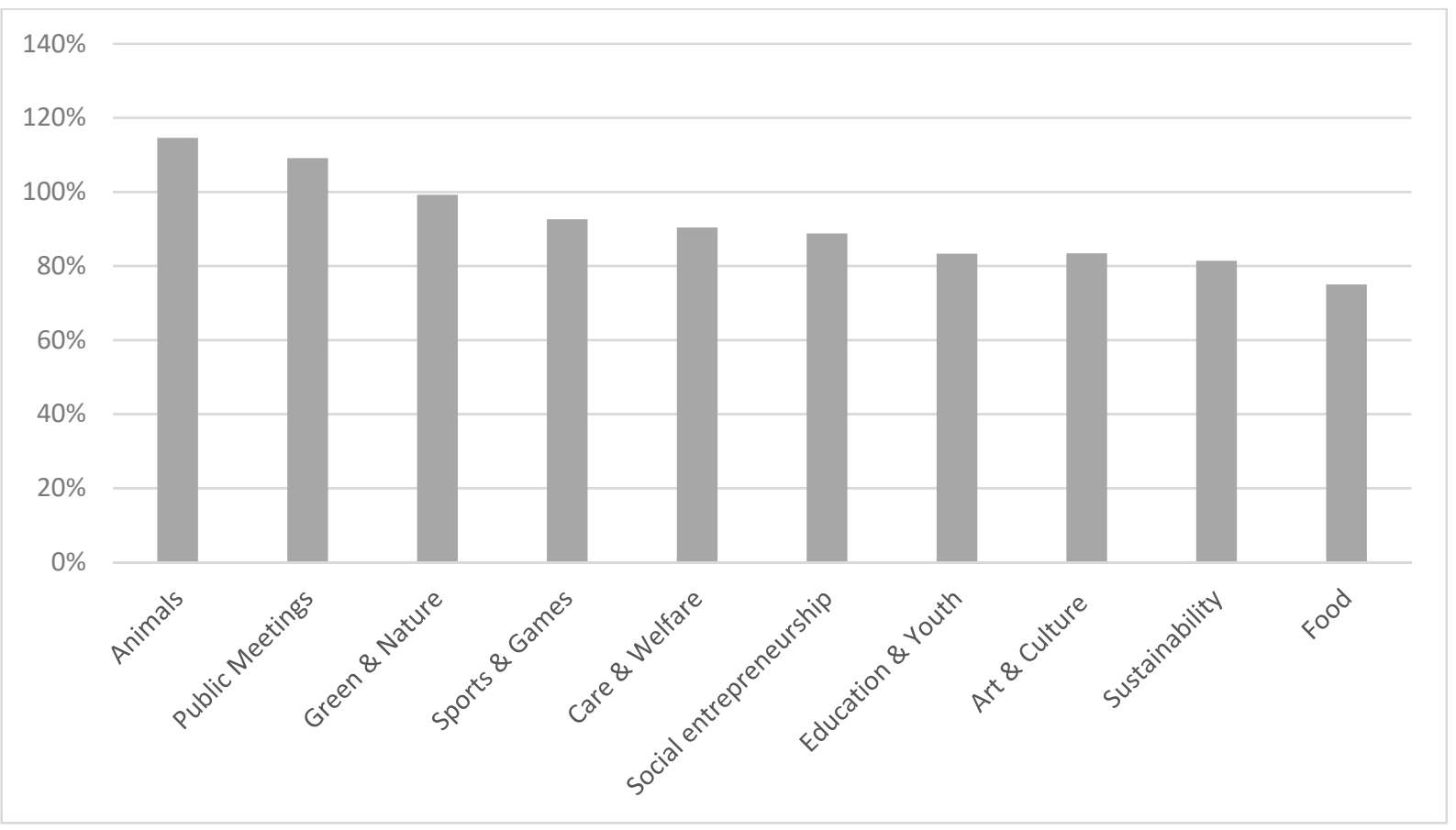

Figure 2. Average success ratios of civic crowdfunding projects, i.e., ratios of realized earnings and target earnings, per project theme (vertical axis: average success ratio per project theme; horizontal axis: project theme). 
To examine the influence of the civic crowdfunding theme, we can use ten different dummy variables each indicating a theme in the mixed regression model. However, to reduce the number of independent variables in our mixed regression models we replaced the ten different dummy variables by only one dummy variable that indicates whether the theme of the project is popular or less popular. The new dummy variable will have a value of 1 for the five project themes with the greatest average success ratios. These themes are Animals, Public Meetings, Green \& Nature, Sports \& Games, and Care \& Welfare (174 projects; average success ratio $100.6 \%$ ). The dummy variable will have a value of 0 for the other five project themes. In this case, Social Entrepreneurship, Education \& Youth, Art $\&$ Culture, Sustainability, and Foods (95 projects; average success ratio 83.8\%).

We use the following campaign characteristics as independent variables in the first mixed regression model: (1) the dummy variable indicating whether the theme of the project is popular or less popular; (2) target amount of money (expressed in terms of thousand Euros); (3) all-or-nothing principle (yes = 1; no = 0); and (4) match-funding (yes $=1 ;$ no $=0)$.

\subsection{The Influence of Campaign Characteristics}

The first mixed regression model examines which campaign characteristics support civic crowdfunding campaigns (see Table 2). The table reveals that the theme has a significant influence on the success of the funding campaign ( $p$ value $<0.05)$. The more popular a theme is, the more helpful it is to fund a campaign successfully and therefore also to develop a successful campaign. A possible explanation could be that certain themes encourage private investors and organizations more to fund them than other themes (c.f. Charbit and Desmoulins 2017; Brent and Lorah 2019). Our results confirm this and start specifying the nature of the project. Furthermore, it is indicated that the target earnings negatively influence the success of the crowdfunding campaign $(p$ value $<0.01)$. This means that the higher the target earnings are set, the less likely it is that these targets will be reached, indicating that the funding of the campaign is less successful and thereby also contributes to a less successful civic crowdfunding campaign. Furthermore, the model reveals that match-funding positively influences the success of the crowdfunding campaign ( $p$ value $<0.01$ ). This means that if the amount of money that is funded by private persons or organizations is also funded by the municipality this contributes to the success of a crowdfunding campaign. This corresponds to the findings of Charbit and Desmoulins (2017), and Brent and Lorah (2019, p. 129), which suggest that an active and contributing role of the government in civic crowdfunding helps in the success of it. Finally, the all-or-nothing principle turns out to be not statistically significant.

Table 2. Results of mixed regression model with campaign characteristics as independent variables.

\begin{tabular}{ccc}
\hline Dependent Variable: Ratio of Realized Funding and Target Funding \\
\hline Independent Variable & Estimate & SE \\
\hline Popular verses less popular theme of project (popular $=1 ;$ less & 0.147 & $0.060^{* *}$ \\
popular $=0$ ) & -0.027 & $0.001 * *$ \\
Target funding $(* € 1000)$ & -0.027 & 0.105 \\
All-or-nothing principle $($ yes $=1 ;$ no $=0)$ & 0.330 & $0.058^{* * *}$ \\
Match-funding $($ yes $=1 ;$ no $=0)$ & &
\end{tabular}

Note: ${ }^{*}{ }^{* *} /{ }^{* * *}$ denote significance at the $0.10 / 0.05 / 0.01$ level.

\subsection{The Influence of Local Demographic Characteristics}

In addition to the campaign characteristics, we performed a second mixed regression model to analyze the influence of local demographic characteristics on the success of civic crowdfunding campaigns. The following demographic characteristics of the project neighborhoods were used as independent variables in the second mixed regression model: (1) population density, (2) dummy variables indicating a specific age category with the age group 15-24 years as reference group, (3) percentage of households with high income, 
(4) percentage one-person households, (5) dummy variables indicating a specific province of the Netherlands with North as reference group. The results of the mixed regression model with the demographic characteristics as independent variables are presented in Table 3.

Table 3. Results of mixed regression model with demographic characteristics of neighborhoods as independent variables.

\begin{tabular}{|c|c|c|}
\hline \multicolumn{3}{|c|}{ Dependent Variable: Ratio of Realized Funding and Target Funding } \\
\hline Independent Variable & Estimate & SE \\
\hline Population density $(* 1000$ inhabitants) & 0.0123 & $0.001^{* * *}$ \\
\hline Age group $0-14$ years $($ yes $=1 ;$ no $=0)$ & 4.680 & $1.730 * * *$ \\
\hline Age group $15-24$ years $($ yes $=1 ;$ no $=0$ ) & \multicolumn{2}{|c|}{ reference group } \\
\hline Age group $25-44$ years $($ yes $=1 ;$ no $=0$ ) & 2.861 & $1.697 *$ \\
\hline Age group $45-64$ years $($ yes $=1 ;$ no $=0$ ) & 1.003 & 1.650 \\
\hline Age group $65->$ years $($ yes $=1 ;$ no $=0)$ & 2.118 & 1.633 \\
\hline $\begin{array}{l}\text { Percentage households with high income } \\
\qquad(\text { yes }=1 ; \text { no }=0)\end{array}$ & 0.011 & 0.008 \\
\hline One-person household $($ yes $=1 ;$ no $=0$ ) & 0.419 & 0.291 \\
\hline North & \multicolumn{2}{|c|}{ reference group } \\
\hline Gelderland & 0.225 & 0.178 \\
\hline Utrecht & 0.263 & 0.184 \\
\hline Flevoland & 0.160 & 0.225 \\
\hline North Holland & 0.310 & 0.171 * \\
\hline South Holland & 0.567 & $0.168^{* * *}$ \\
\hline North Brabant & 0.324 & $0.186^{*}$ \\
\hline Limburg & 0.284 & 0.192 \\
\hline
\end{tabular}

Note: ${ }^{*}{ }^{* *} /{ }^{* * *}$ denote significance at the $0.10 / 0.05 / 0.01$ level. We randomly chose the age group $0-14$ years as the reference group. As a result, the regression coefficient is set to the value 0 .

The findings show that in more highly urbanized neighborhoods more money is donated to civic crowdfunding campaigns, and therefore also support the success of such campaigns ( $p$ value $<0.01)$. In addition, neighborhoods in which families have young children ( 0 to 15 years of age) are more willing to invest in civic crowdfunding campaigns than neighborhoods in which young adults (for instance, students) live (15 to 25 years of age). A possible explanation is that families with young children feel more connected with a theme of a campaign and therefore are more willingly to invest. Finally, the model shows that neighborhoods that are in the provinces North Holland, South Holland and North Brabant spend relatively large amounts of money on civic crowdfunding campaigns ( $p$ value $<0.1, p$ value $<0.01$, and $p$ value $<0.1$ ). The Northern provinces on the other hand, seem to spend relatively less money on these campaigns. A possible explanation is that the provinces North Holland, South Holland, and North Brabant are more urbanized and social ties within neighborhoods are looser. For this reason, more traditional network related funding approaches do not work, and governments and others are searching for other approaches to funding. It could also be that in these areas there are individuals who are more active and experienced in realizing civic crowdfunding campaigns.

In addition, we also try to make a connection between all used explanatory variables. For this we run a mixed regression model with all statistically significant characteristics of both the civic crowdfunding campaigns and the local neighborhoods. This model is expanded with the interaction effects between the first group of explanatory variables and the second group of explanatory variables. There appears to be a statistically significant positive interaction effect for a popular theme of a civic crowdfunding project in the province of South Holland (significance 0.009) and the application of match-funding in the province South Holland (significance 0.025).

To conclude, the mixed regression models shows that several campaign characteristics and local demographic characteristics are statistically significantly related to successfully funding civic crowdfunding campaigns. Furthermore, the combination of campaign char- 
acteristics and local demographic characteristics is also important. We therefore conclude that both campaign characteristics and local demographic characteristics facilitate civic crowdfunding campaigns and therefore also contribute to the success-measured as being funded-of such a campaign.

\section{Conclusions and Discussion}

Civic crowdfunding is increasingly perceived by local governments as a new instrument to engage citizens. It is seen as a valuable additional tool to increase citizen engagement. By exploring characteristics that support the funding of civic crowdfunding campaigns, our study reveals that there are several factors that influence the success of such a campaign.

It turns out that the urbanization rate of a neighborhood has a positive influence on the success of a civic crowdfunding campaign, an assumption first expressed by Parker and Johansson (2012). Furthermore, our study shows that the percentage of high-income households in a neighborhood has no influence on the success of a campaign. Kim and Khang (2014), studying the funding of elections in the US, as well as Praharaj et al. (2017) and Brent and Lorah (2019) produce similar results. In addition, we found that the theme of a civic crowdfunding project is related to the success of a civic crowdfunding campaign. This finding is consistent with Kusumarani and Zo (2019), who confirmed empirically this finding for the US context and the theoretical paper of Charbit and Desmoulins (2017).

Moreover, it turns out that the use of match-funding, specific age categories and specific provinces in the Netherlands positively influence funding a civic crowdfunding campaign and thereby facilitate the success of it. We also found that the target amount of money influences negatively the success of a civic crowdfunding campaigns, and therefore might not be helpful. Consequently, we revealed that the combination of campaign characteristics and neighborhood characteristics contribute to the success of civic crowdfunding campaigns.

As indicated, various characteristics of the projects and demographic characteristics of the neighborhoods are relevant for a civic crowdfunding campaign. In addition, the combination of these two types of variables can also be important. For example, a popular project theme or the application of match-funding on the one hand and a neighborhood in South Holland on the other hand led to a relatively high ratio between amount of realized funding and amount of target funding.

The results of this study also give us the opportunity to reflect on the impact of ITenabled forms of citizen engagement on the relationship between local governments and citizen engagement. Suggestions can be made regarding the 'political economy of civic crowdfunding' (Brent and Lorah 2019). Civic crowdfunding can question the role of local governments as funders. Are they the best mechanism to redistribute taxpayer's money over social projects, when citizens themselves can decide by using civic crowdfunding? Would civic crowdfunding limit the role of local governments in funding social projects? These are not easy questions to answer because they are related to political orientations. Civic crowdfunding could suggest-within a specific political orientation-that the government does not have to fund social projects on its own. Still, some involvement of the government will exist in civic crowdfunding. In development of the neighborhood the local government has a wide range of other responsibilities that imply involvement in projects that are being 'crowdfunded'.

This does not have to imply that the role of the local government cannot change given these new technologies. For example, municipalities do not have to be the only funders of certain projects, such as a playground. They can act as a facilitator and initiator also, where citizens themselves take a role in acquiring funding. Also, by using match-funding the local government can seriously stimulate citizens to engage as funder in a project. Of course, this is an issue that is related to political standpoints and ideology. Not every project that is embraced by communities should be co-funded by local governments. It should fit in with municipal policies to a certain degree. Here, a civic crowdfunding initiative can question 
the democratic legitimacy of local governments, to a certain extent. What happens when projects get a lot of funding by large groups of citizens and these projects run counter to the policies of local authorities?

Our findings also give some insight into the role of individuals in developing their communities by using technology, as is discussed by various authors (e.g., Charbit and Desmoulins 2017; Brent and Lorah 2019). We suggest that technology can be of assistance in funding projects. It can be debated whether it replaces existing social ties: it could be the other way around too. The success of a campaign depends on the social network of the initiators. As such, civic crowdfunding is an addition to existing networks in communities.

These issues are related to the role of the local governments in civic crowdfunding projects within neighborhoods. Again, some could suggest that civic crowdfunding makes governments less relevant. By crowdfunding, citizens can distribute money-which they would otherwise pay in taxes-to the most needed projects. Our study suggests that this is more complex. The role of local governments affects the success of a certain project. In addition, even if civic crowdfunding could look like an efficient redistribution mechanism to replace part of the role of municipalities, then there are still other political reasons for not using crowdfunding as the only means for funding social projects.

Next to our assessment of project specifications, the relationship with demographic conditions gives some interesting insights too. For example, the difference between urban and rural areas seems relevant here. There could be a variety of reasons for this. To name two possibilities: maybe in cities more people are more readily adaptive to new technologies, or they embrace new opportunities earlier because traditional ways of fundraising do not work. Future research should determine if this is the case.

Also relevant in our study seems to be that civic crowdfunding is first adapted by higher educated (young) people. Here, especially parents with young children are a relevant group. It can be suggested that this group is digitally literate and locally active. This could limit the application of civic crowdfunding by local communities as only a particular part of the community will be able to engage in social projects by using these means.

During our study we became aware of various limitations. First, we used the dataset of ten different civic crowdfunding platforms that focused on developing social projects. There are other civic crowdfunding platforms that have a broader scope, which could lead to other target groups and other outcomes. Also, in the Netherlands there are some platforms that focus on a small niche only. For example, the platform "Voor de Kunst" [for art] enables the support of art projects only, of which some have a community orientation only. Also, the initiatives on the platforms we assessed were most often the result of cooperation between local governments and the platforms. This has impacted on the selection of municipalities and the selection of neighborhoods.

Nevertheless, this study aims to improve the understanding of civic crowdfunding in practice. Therefore, it is another step in understanding the application of civic crowdfunding in local communities in relation to the role of local governments. We fit another piece into the puzzle. Where Brent and Lorah (2019) focused on civic crowdfunding in minority communities, we went a step further by taking a much broader group of projects, and more explanatory factors such as demographic neighborhood characteristics and campaign characteristics into account. Also, we add a European Union perspective, a region where governments tend to be more active in community development then in the US. Here, it can also be relevant that the Netherlands is a country in which trust in the government by citizens is relatively high, so individuals will probably participate more readily in a voluntary program set up by the government. The implications for practice are relevant for governments, civic crowdfunding platforms, and donators. We suggest which levers help to achieve a successful civic crowdfunding campaign. The theme, the target amount of money, the age of the target group, and match-funding by the government seem to be some of the relevant determinants. 
Author Contributions: Formal analysis, K.V.M.; Methodology, V.S. and K.V.M.; Writing-original draft, K.V.M., V.S. and F.J.D.G.; Writing-review \& editing, V.S. and K.V.M. All authors have read and agreed to the published version of the manuscript.

Funding: This research received no external funding.

Institutional Review Board Statement: Not applicable.

Informed Consent Statement: Not applicable.

Data Availability Statement: The data are available upon request.

Conflicts of Interest: The authors declare no conflict of interest.

\section{References}

Ahlers, Gerrit. K. C., Douglas Cumming, Christine Guenther, and Denis Schweizer. 2015. Signaling in Equity Crowdfunding. Entrepreneurship Theory and Practice 39: 955-80. [CrossRef]

Baber, Hasnan. 2020. Intentions to participate in political crowdfunding-from the perspective of civic voluntarism model and theory of planned behavior. Technology in Society 63: 101435. [CrossRef]

Bastian, Lisa. 2015. The New Economy: Crowdfunding for Civic Projects. Area Development Site and Facility Planning 49 : 14.

Behl, Abhishek, and Pankaj Dutta. 2020. Engaging donors on crowdfunding platform in Disaster Relief Operations (DRO) using gamification: A Civic Voluntary Model (CVM) approach. International Journal of Information Management 54: 102140. [CrossRef]

Brent, Daniel, and Katie Lorah. 2019. The economic geography of civic crowdfunding. Cities, 122-30. [CrossRef]

Charbit, Claire, and Guillaume Desmoulins. 2017. Civic Crowdfunding: A Collective Option for Local Public Goods? OECD Regional Development Working Papers 2017/1. Paris: OECD Publishing.

Cheung, Johnson Chung-Sing, and Justin Mark Rogers. 2020. Civic crowdfunding for social work research: Opportunities, challenges and strategies. British Journal of Social Work. [CrossRef]

Cho, Seongkyung, Karen Mossberger, Davin Swindell, and John David Selby. 2020. Experimenting with Public Engagement Platforms in Local Government. Urban Affairs Review. [CrossRef]

Colasanti, Nathali, Rocco Frondizi, and Marco Meneguzzo. 2018. Higher education and stakeholders 'donations: Successful civic crowdfunding in an Italian university. Public Money E Management 38: 281-88.

Crowdfundingcijfers[crowdfunding statistics]. 2020. Available online: Crowdfundingcijfers.nl/crowdfunding-in-nederland-2019/2020 (accessed on 26 March 2020).

Davies, Rodrigo. 2014. Civic crowdfunding as a marketplace for participation in urban development. Presented at the Internet, Policy \& Politics Conference, Stanford, CA, USA, September 1; pp. 1-25.

Davies, Rodrigo. 2015. Three provocations for civic crowdfunding. Information, Communication \& Society 18: 342-55.

Doan, Mai Anh, and Margalit Toledano. 2017. Beyond organization-centred public relations: Collective action through a civic crowdfunding campaign. Public Relations Review 44: 37-46. [CrossRef]

Douw, and Koren. 2017. Crowdfunding in Nederland 2016. De Status van Crowdfunding in Nederland. Available online: douwenkoren. $\mathrm{nl}$ (accessed on 28 April 2020).

Fischer, Frank. 2000. Citizens, Experts, and the Environment: The Politics of Local Knowledge. Duke: University Press.

Gandhinagar. 2015. Government of Gujara Introduces India's First Civic Crowdfunding Platform. New York: Pr Newswire.

Gaventa, John. 2002. Exploring citizenship, participation and accountability. IDS Bulletin 33: 1-14. [CrossRef]

Hair, Joseph F., William C. Black, Barry J. Babin, and Rolph E. Anderson. 2010. Multivariate Data Analysis: A Global Perspective. Boston: Pearson.

Hsu, Angel, Zhi Yi Yeo, and Amy Weinfurter. 2020. Emerging digital environmental governance in China: The case of black and smelly waters in China. Journal of Environmental Planning and Management 63: 14-31. [CrossRef]

Hummel, Daniel. 2016. Civic crowd-funding: A potential test of the voluntary theory of public finance for public capital goods. Journal of Public Budgeting, Accounting and Financial Management 28: 171-95. [CrossRef]

Irvin, Renée A., and John Stansbury. 2004. Citizen participation in decision making: Is it worth the effort? Public Administration Review 64: 55-65. [CrossRef]

Johnson, Peter A., Pamela J. Robinson, and Simone Philpot. 2020. Type, tweet, tap, and pass: How smart city technology is creating a transactional citizen. Government Information Quarterly 37. [CrossRef]

Kim, Yeojin, and Hyoungkoo Khang. 2014. Revisiting civic voluntarism predictors of college students' political participation in the context of social media. Computers in Human Behavior 36: 114-21. [CrossRef]

Kusumarani, Riri, and Hangjung Zo. 2019. Why people participate in online political crowdfunding: A civic voluntarism perspective. Telematics and Informatics 41: 168-81. [CrossRef]

Massolution. 2015. The Crowdfunding Industry Report. Pittsburgh: Massolution.

Miglo, Anton. 2020. Crowdfunding in a Competitive Environment. Journal of Risk and Financial Management 13: 39. [CrossRef]

Mollick, Ethan. 2014. The dynamics of crowdfunding: An exploratory study. Journal of Business Venturing 29: 1-16. [CrossRef]

Morell, Mayo Fuster, Enric Senabre Hidalgo, and Enrique Rodríguez. 2020. Goteo. org civic crowdfunding and match-funding data connecting Sustainable Development Goals. Scientific Data 7: 1-10. 
Mueller, Johannes, Hangxin Lu, Artem Chirkin, Bernhard Klein, and Gerhard Schmitt. 2018. Citizen design science: A strategy for crowd-creative urban design. Cities 72: 181-88. [CrossRef]

Nabatchi, Tina, and Matt Leighninger. 2015. Public Participation for the 21ste Century Democracy. New Jersey: John Wiley \& Sons.

Parker, Peter, and Magnus Johansson. 2012. Challenges and potentials in collective management of urban commons. In Multi-Facted Nature of Collaboration in the Contemporary World. Malmö: Vega Press, pp. 92-113.

Porter, Amandaa J., and Marce Veenswijk. 2018. Narrative "end states" and the dynamics of participation in civic crowdfunding. International Journal of Communications 12: 2367-86.

Praharaj, Sarbeswar Praharaj, Jung Hoorn Han, and Scott Hawken. 2017. Innovative civic engagement and digital urban infrastructure: Lessons from 100 smart cities mission in India. Procedia Engineering 180: 1423-32. [CrossRef]

Quaintance, Zack. 2017. What's New in Civic Tech: New York City Announces Crowdfunding Program for Women Entrepreneurs. Chicago: TCA Regional News.

Roberts, Nancy. 2004. Public deliberation in an age of direct citizen participation. American Review of Public Administration 34: 315-53. [CrossRef]

Rowe, Gene, and Lynn J. Frewer. 2000. Public participation methods: A framework for evaluation. Science, Technology \& Human Values 25: 3-29.

Siebers, Vinitha, and Jacob Torfing. 2018. Co-creation as a new form of citizen engagement: Comparing Danish and Dutch experiences at the local government level. International Public Management Review 18: 187-208.

Stiver, Alexandra, Leonor Barroca, Shailey Minocha, Mike Richards, and Dave Roberts. 2014. Civic crowdfunding research: Challenges, opportunities, and future agenda. New Media \& Society 17: 249-71.

Ullah, Saif, and Yullin Zhou. 2020. Gender, Anonymity and Team: What Determines Crowdfunding Success on Kickstarter. Journal of Risk and Financial Management 13: 80. [CrossRef]

Wenzlaff, Karsten. 2020a. Civic Crowdfunding: Four Perspectives on the Definition of Civic Crowdfunding. In Advances in Crowdfunding. Cham: Palgrave Macmillan, pp. 441-72.

Wenzlaff, Karsten. 2020b. Civic Crowdfunding-Overview of the Literature and Contribution to Academic Debate. Cham: Palgrave Macmillan.

West, Brady T., Kathleen B. Welch, and Andrzej T. Galecki. 2007. Linear Mixed Models: A Practical Guide Statistical Software. New York: Chapman \& Hall/CRC. 